\title{
PENINGKATAN HASIL BELAJAR PENDIDIKAN AGAMA KRISTEN MELALUI MODEL PEMBELAJARAN KOOPERATIF TIPE TWO STAY TWO STRAY BAGI SISWA KELAS 5 SD NEGERI TOISAPU
}

\author{
Nathalia Y. Johannes \\ Dosen Program Studi PGSD, FKIP-Unpatti Ambon \\ email:jo_nathal@yahoo.co.id
}

\section{ARTICLE INFO}

Article History:

Accepted 13 April 2016

Available online 29 April 2016

Keywords:

Pendidikan Agama Kristen, Tipe Two Stay Two Stray, Siswa SD, hasil belajar.

\begin{abstract}
Pembelajaran Pendidikan Agama Kristen pada hakekatnya berpangkal atau berpokok kepada Allah sendiri karena Allah-lah yang menjadi Pendidik Agung bagi umat-Nya. Oleh sebab itu pembelajaran Pendidikan Agama Kristen perlu dirancang dengan baik, dengan metode yang tepat maupun cara pembelajaran yang kreatif dan efisien. Rancangan pembelajaran tersebut harus mampu menjadikan anak memiliki landasan kepercayaan yang kokoh kepada Tuhan Yesus.Sekolah Dasar adalah pondasi awal bagi siswa untuk bisa meneladani hal-hal yang baik.Pertumbuhan iman anak yang signifikan kepada Tuhan Yesus patut dibangun pada masa ini.Oleh sebab itu Pendidikan Agama Kristen sebagai sebuah mata pelajaran yang menekankan pendidikan karakter dan budi pekerti membutuhkan sebuah model pembelajaran yang menarik bagi siswa. Model yang mampu memotivasi siswa untuk berbicara, mengeluarkan pendapat serta memiliki hubungan kerja sama antara satu siswa dengan siswa yang lain. Kemampuan berbicara dan mengeluarkan pendapat tentunya sangat baik untuk mendorong siswa dalam memiliki kecakapan untuk bersaksi kepada orang lain tentang perbuatan-perbuatan Allah dalam dirinya. Dengan rancangan yang tepat, hasil belajar dalam Pendidikan Agama Kristen tentu akan meningkat. Penelitian ini dilakukan dengan menggunakan tipe penelitian tindakan kelas yang bertempat di SD Negeri Toisapu Ambon.Penelitian dilakukan untuk meningkatkan hasil belajar siswa melalui model pembelajaran TSTS.Hasil penelitian menunjukkan bahwa model pembelajaran TSTS berhasil meningkatkan hasil belajar siswa dalam pembelajaran Pendidikan Agama Kristen.
\end{abstract}




\section{PENDAHULUAN}

Pembelajaran merupakan suatu proses yang terdiri dari serangkaian aktivitas yaitu mulai dari persiapan, pelaksanaan dan evaluasi pembelajaran. Ketiga hal tersebut merupakan rangkaian utuh yang tidak dapat dipisahkan.Persiapan pembelajaran tidak hanya dilakukan oleh guru, siswa pun juga harus memiliki kesiapan untuk belajar.Kesiapan siswa, baik fisik maupun mental juga merupakan hal penting. Jadi esensi persiapan proses pembelajaran adalah kesiapan segala hal yang diperlukan untuk berlangsungnya proses pembelajaran sehingga dalam pelaksanaan pembelajaran nantinya dapat terjadi transfer ilmu antara guru dan siswa dengan baik. Apabila pelaksanaannya baik, maka tujuan pembelajaran tersebut diharapkan dapat dicapai (Sudjana, 2004).

Pembelajaran kini bukan lagi dipandang sebagai pembelajar saja, melainkan pembelajaran harusnya mengedepankan siswa sebagai subyek dalam pembelajaran.Pembelajaran sendiri harus dirancang untuk mengaktifkan siswa. Hal ini sejalan dengan apa yang ditegaskan Mulyasa (2007) bahwa pembelajaran dikatakan berhasil dan berkualitas apabila seluruhnya atau setidak-tidaknya sebagian besar $(75 \%)$ peserta didik terlibat secara aktif, baik fisik, mental maupun sosial dalam proses pembelajaran, disamping menunjukkan kegairahan belajar yang tinggi, semangat belajar yang besar dan rasa percaya pada diri sendiri.

Pendidikan mempunyai makna sebagai proses mengubah tingkah lakuanak didik agar menjadi manusia dewasa yang mampu hidup mandiri dansebagai anggota masyarakat dalam lingkungan alam sekitar individu ituberada. Pendidikan tidak hanya mencakup pengembangan intelektualitas saja,akan tetapi lebih ditekankan pada proses pembinaan kepribadian anak didiksecara menyeluruh sehingga anak menjadi lebih dewasa (Sungkono,2009).Meningkatkan mutu pendidikan menuntut kerja keras berbagai pihak.Mulai dari tenaga kependidikan, orang tua, peserta didik, masyarakat danpemerintah untuk mencapai tujuan akhir yaitu sumber daya manusia yangberkualitas, sehingga peserta didik perlu dipersiapkan sejak dini. Kualitas pembelajaran dapat dilihat dari dua sisi yang sama pentingnya, yakni sisi proses dan sisi hasil belajar. Proses belajar berkaitan dengan pola perilaku siswa dalam mempelajari bahan pelajaran; sedangkan hasil belajar berkaitan dengan perubahan perilaku yang diperoleh sebagai pengaruh dari proses belajar. Hasil belajar merupakan salah satu faktor yang dapat menentukan proses belajar. Dengan kata lain, bagaimana seharusnya siswa belajar, akan sangat ditentukan oleh apa hasil yang ingin diperoleh oleh siswa (Sanjaya, 2009).

Belajar mengajar pada dasarnya adalah interaksi atau hubungan timbal balik antara guru dan siswa dalam situasi pendidikan.Oleh karena itu, gurudidalam mengajar dituntut kesabaran, keuletan dan sikap terbuka disampingkemampuan dalam situasi belajar mengajar yang lebih aktif dan siswa jugadituntut adanya semangat dan dorongan.Penggunaan metodekonvensional pada saat pembelajaran Pendidikan Agama Kristen berlangsung, tidak relevan untukmencapai kompetensi dua ranah (kognitif dan afektif).Hal ini dikarenakanmetode konvensional hanya dapat mengembangkan ranah kognitif saja,sedangkan afektif dan psikomotor tidak tercapai. 
Betapa pentingnya sebuah model pembelajaran dalam proses pembelajaran supaya bisa berhasil. Model pembelajaran ini sangat dibutuhkan juga dalam Pendidikan Agama Kristen di Sekolah Dasar.Pendidikan agama pada dasarnya bertujuan agar siswa menjadi anak yang beriman dan bertaqwa terhadap Tuhan Yang Maha Esa, dan berbudi pekerti luhur. Tujuan ini hanya bisa dicapai jika model pembelajaran yang digunakan mampu merangsang anak untuk ikut terlibat aktif dalam proses pembelajaran. Keaktifan anak dalam pembelajaran terutama dalam pembelajaran Pendidikan Agama Kristen menjadi faktor penting keberhasilan pembelajaran dan juga mampu memotivasinya agar bisa bersaksi dalam hidup setiap hari.

Keberhasilan tersebut terwujud apabila Pendidikan Agama Kristen di sekolah dasar dilaksanakan sebaik-baiknya, dengan metode yang tepat maupun cara pembelajaran yang kreatif dan efisien sehingga anak memiliki landasan kepercayaan yang kokoh kepada Tuhan Yesus. Sekolah Dasar adalah pondasi awal bagi siswa untuk bisa meneladani hal-hal yang baik.Pertumbuhan iman anak yang signifikan kepada Tuhan Yesus patut dibangun pada masa ini.Oleh sebab itu Pendidikan Agama Kristen sebagai sebuah mata pelajaran yang menekankan pendidikan karakter dan budi pekerti membutuhkan sebuah model pembelajaran yang menarik bagi siswa. Model yang mampu memotivasi siswa untuk berbicara, mengeluarkan pendapat serta memiliki hubungan kerja sama antara satu siswa dengan siswa yang lain. Kemampuan berbicara dan mengeluarkan pendapat tentunya sangat baik untuk mendorong siswa dalam memiliki kecakapan untuk bersaksi kepada orang lain tentang perbuatan-perbuatan Allah dalam dirinya.

Penekanan tentang pentingnya kecakapan siswa dalam mengimani karya Allah tidak hanya menjadi tujuan dalam pendidikan agama Kristen tetapi sudah merupakan dasar sebab penekanan ini bersumber dari Alkitab atau seperti yang dikemukakan Cully (2001), bahan pengajaran pokok pendidikan agama Kristen ditemukan dalam kitab-kitab Injil. Sebab pesan sentral dari Alkitab adalah pemberitaan tentang tindakan Ilahi .Dalam tradisi orang Israel "Shema" atau perintah Tuhan yang wajib dijalankan, karena hanya dengan pedoman itu umat tidak keluar dari pemeliharaan dan perlindungan Tuhan. Yang seutuhnya tersimpul dalam sebutan "Taurat".Ulangan 6:4-9 sering disebut sebagai syema, suatu panggilan bagi Israel untuk mendengar firman Tuhan, "dengarlah...apa yang kuperintahkan kepadamu pada hari ini haruslah engkau perhatikan, haruslah engkau mengajarkannya berulangulang kepada anak-anakmu dan membicarakannya apabila engkau duduk di rumahmu, apabila engkau sedang dalam perjalanan, apabila engkau berbaring dan apabila engkau bangun. Haruslah juga engkau mengikatkannya sebagai tanda pada tanganmu dan haruslah itu menjadi lambang di dahimu, dan haruslah engkau menuliskannya pada tiang pintu rumahmu dan pada pintu gerbangmu."(Ulangan 6:69).

Melalui Syema Israel diajar untuk memilih persekutuan yang intim dengan Tuhan sebagai prioritas utama. Seluruh aspek kehidupan Israel didasari oleh hubungan cintanya dengan Tuhan. Di dalam cinta ini terkandung komitmen dan kesetiaan yang menyeluruh dan total. Syema ini, pertama, harus tertanam dalam hati 
orang Israel; kedua, harus tertanam dalam hati anak-anak Israel; ketiga, harus menjadi bagian hidup sehari-hari mereka; keempat, harus menjadi identitas pribadi mereka; dan kelima, menjadi identitas keluarga serta masyarakat Israel. Tidak ada satu bagian pun dalam kehidupan orang Israel yang terlepas dari relasi mereka yang penuh kasih kepada Tuhan. Betapa pentingnya relasi dengan Tuhan bagi anak-anak pada masa itu (tentu penting juga pada generasi kini) sehingga diberikan penekanan untuk mengajarkannya berulang-ulang. Sebagai mata pelajaran yang masuk dalam Kurikulum Nasional, peranan Pendidikan agama Kristen ialah membina relasi antara siswa dengan Tuhan Sang Pemberi hidup.Relasi antara siswa di sekolah dasar kepada Tuhan bisa dibina dengan menggunakan model pembelajaran yang memotivasinya untuk bisa berbicara tentang kebaikan Tuhan dalam hidupnya.Paradigma ini sejalan dengan pemikiran, Thomas M. Groome (dalam Nuhamara, 1992) mengungkapkan tujuan pendidikan Agama Kristen adalah agar manusia mengalami hidupnya sebagai respon terhadap kerajaan Allah di dalam Yesus Kristus.Perwujudan nilai alkitabiah ini sangat dibutuhkan dalam pelaksanaan pembelajaran Pendidikan Agama Kristen. Perwujudannya tidak dapat dilepaspisahkan dari metode dan model pembelajaran yang digunakan guru pada saat proses pembelajaran di kelas. Pendidikan agama Kristen pada akhirnya harus bisa mendidikan anak untuk bisa menyatakan imanya dalam praktik kehidupan setiap hari (Enklaar, 2001).

Model TSTS adalah salah satu tipe dalam model pembelajaran kooperatif yang memberikan kesempatan kepada kelompok untuk membagikan hasil dan informasi ke kelompok lain (Lie, 2008). Jadi lima unsur proses belajar kooperatif yang terdiri atas: saling ketergantungan positif, tanggung jawab perseorangan, tatap muka, komunikasi antar kelompok dan evaluasi proses kelompok dapat terlaksana. Pada saat anggota kelompok bertamu ke kelompok lain, maka akan terjadi proses pertukaran informasi yang bersifat saling melengkapi dan pada saat kegiatan dilaksanakan maka akan terjadi proses tatap muka antar siswa dimana akan terjadi komunikasi baik dalam kelompok maupun antar kelompok sehingga siswa tetap mempunyai tanggung jawab perseorangan. Tanggung jawab perseorangan dan kelompok yang dibangun melalui model ini untuk bisa saling bertukar informasi menjadi dasar untuk menumbuuhkembangkan kekuatan spiritual anak dalam bersaksi sebagai responsnya terhadap Tri Tugas Gereja.Model TSTS sangat menarik dan mampu mengaktifkan siswa di kelas.Selain itu, di kelas 5 SD Negeri Toisapu belum pernah menerapkan model pembelajaran TSTS ini.Dengan demikian penelitian ini dilakukan dalam rangka mengkaji Peningkatan Hasil Belajar Pendidikan Agama Kristen Melalui Model Pembelajaran Kooperatif Tipe Two Stay Two Stray Bagi Siswa kelas 5 SD Negeri Toisapu.

\section{METODE PENELITAN}

Penelitian ini merupakan penelitian Tindakan Kelas dengan menggunakan Model pembelajaran kooperatif tipe Two Stay Two Stray (TSTS). Secara khusus penelitian ini bertujuan untuk meningkatkan hasil belajar siswa karena mengingat bahwa PTK bertujuan memperbaiki, meningkatkan mutu pembelajaran di kelas. Kegiatan penelitian ini dilakukan dengan mengikuti alur pokok sebagai berikut: (1) 
perencanaan, (2)pelaksanaan tindakan, (3) pengamatan atau observasi, dan (4) refleksi dan perancangan ulang untuk siklus berikutnya.Menurut Rusman(2010) keunggulan pembelajaran kooperatif sendiri antara lain mengembangkan kegembiraan yang sejati, memungkinkan para siswa saling belajar mengenai sikap, keterampilan, informasi, perilaku sosial dan pandangan, meningkatkan rasa saling percaya kepada sesama manusia, meningkatkan motivasi belajar intrinsik dan meningkatkan sikap positif terhadap belajar dan pengalaman belajar. Model pembelajaran Tipe Two Stay Two Stray (TSTS) adalah salah satu model pembelajaran kooperatif. Model pembelajaran ini dikembangkan oleh Spencer Kagan pada tahun 1992 (Fitria, 2010) dan biasa digunakan bersama dengan model Numbered Heads atau model Kepala Bernomor. Struktur Two Stay Two Stray (TSTS) memberi kesempatan kepada kelompok untuk membagi hasil dan informasi dengan kelompok lain. Hal ini dilakukan karena banyak kegiatan belajar mengajar yang diwarnai dengan kegiatan-kegiatan individu. Siswa bekerja sendiri dan tidak diperbolehkan melihat pekerjaan siswa yang lain. Padahal dalam kenyataan hidup di luar sekolah, kehidupan dan kerja manusia saling bergantung satu sama lainnya.

Adapun langkah-langkah model pembelajaran TSTS yang diungkapkan Lie dalam Mirza (2008) adalah sebagai berikut : (a) siswa bekerja sama dalam kelompok berempat seperti biasa; (b) setelah selesai, dua siswa dari masing-masing kelompok akan meninggalkan kelompoknya dan masing-masing bertamu ke kelompok yang lain; (c) dua siswa yang tinggal dalam kelompok bertugas membagikan hasil kerja dan informasi mereka ke tamu mereka; (d) Tamu mohon diri dan kembali ke kolompok mereka snediri dan melaporkan temuan mereka dari kelompok lain; (e) Kelompok mencocokkan dan membahas hasil-hasil kerja mereka.

Berikut skema diskusi model TSTS :

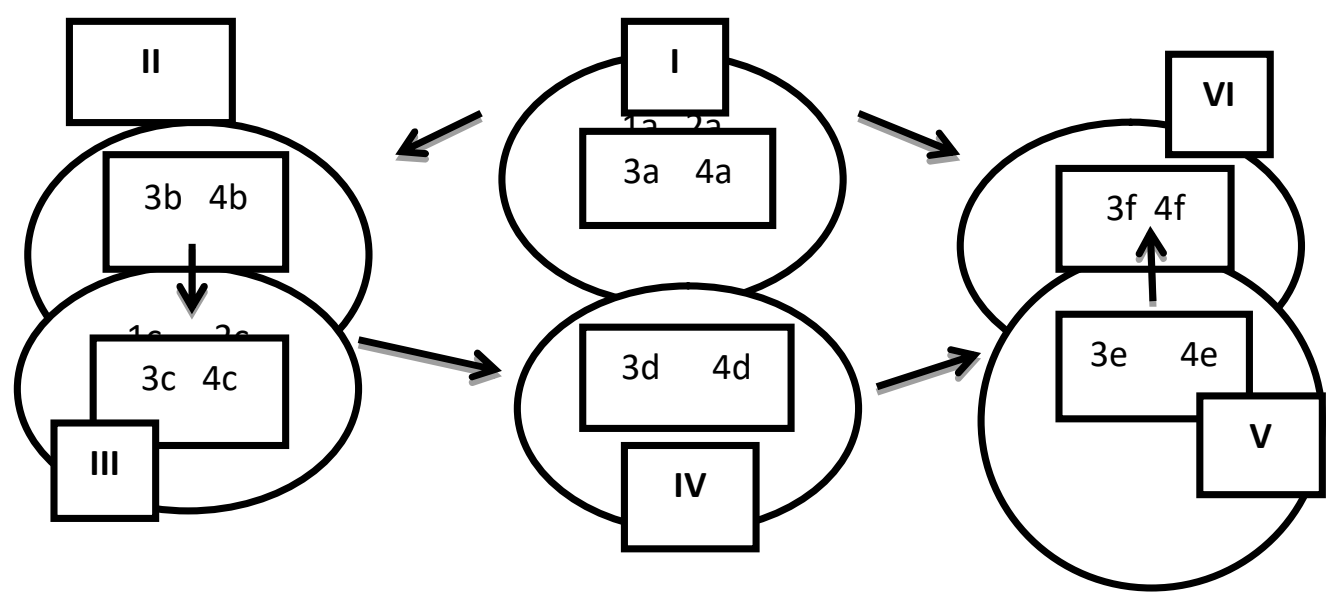

Gambar 1. Skema Diskusi Model Two Stay Two Stray (TSTS) Keterangan :

$\square \quad$ Siswa yang bertamu ke kelompok lain 

berikut :

Pembelajaran kooperatif model TSTS terdiri dari beberapa tahapan sebagai

1. Persiapan.

Pada tahap persiapan ini, hal yang dilakukan guru adalah membuat silabus dan sistem penilaian, desain pembelajaran, menyiapkan tugas siswa dan membagi siswa menjadi beberapa kelompok dengan masing-masing anggota 4 siswa.

2. Presentasi Guru.

Pada tahap ini guru menyampaikan indikator pembelajaran, mengenal dan menjelaskan materi sesuai dengan rencana pembelajaran yang telah dibuat.

3. Kegiatan Kelompok.

Pada kegiatan ini pembelajaran menggunakan lembar kegiatan yang berisi tugas-tugas yang harus dipelajari oleh tiap-tiap siswa dalam satu kelompok.Setelah itu siswa mempelajarinya dalam kelompok kecil (4 siswa) yaitu mendiskusikan masalah tersebut bersama-sama anggota kelompoknya. Masing-masing kelompok menyelesaikan atau memecahkan masalah yang diberikan dengan cara mereka sendiri. Kemudian 2 dari 4 anggota dari masing-masing kelompok meninggalkan kelompoknya dan bertamu ke kelompok lain, sementara 2 anggota yang tinggal dalam kelompok bertugas menyampaikan hasil kerja dan informasi mereka ke tamu. Setelah memperoleh informasi dari 2 anggota yang tinggal, tamu mohon diri dan kembali ke kelompok masing-masing dan melaporkan temuannya serta mencocokkan dan membahas hasil-hasil kerja mereka.

4. Formalisasi

Setelah belajar dalam kelompok dan menyelesaikan permasalahan yang diberikan salah satu kelompok mempresentasikan hasil diskusi kelompoknya untuk dikomunikasikan atau didiskusikan dengan kelompok lainnya.Kemudian guru membahas dan mengarahkan siswa ke bentuk formal.

5. Evaluasi Kelompok dan Penghargaan.

Pada tahap evaluasi ini untuk mengetahui seberapa besar kemampuan siswa dalam memahami materi yang telah diperoleh dengan menggunakan model pembelajaran kooperatif TSTS. Masing-masing siswa diberi kuis yang berisi pertanyaan-pertanyaan dari hasil pembelajaran dengan model TSTS, yang selanjutnya dilanjutkan dengan pemberian penghargaan kepada kelompok yang mendapatkan skor rata-rata tertinggi

Lokasi penelitian bertempat di SD Negeri ToisapuKecamatan Leitimur Selatan.Penelitian ini dilaksanakan pada bulan Juli-September 2015.Subjekpenelitian ini adalah siswa Kristen kelas 5 SD Negeri Toisapu yang berjumlah 20 orang.Untuk memperoleh data dalam penelitian ini, digunakan dua macam instrument yang terdiri dari pretest dan angket skala minatsiswa.Peragkat pembelajaran yang dikembangkan dan digunakan dalam penelitian ini berupa Rencana Pelaksanaan Pembelajaran (RPP) dan Lembar Kerja Siswa (LKS).Teknik Pengumpulan data yang digunakan dalam penelitian ini adalah tes dan angket.Tes digunakan untuk mengumpulkan data hasil belajar siswa yang dilakukan sebelum (pretest) dan sesudah (post test) pelaksanaan 
pembelajaran. Angket digunakan untuk mengetahui sikap siswa mengenai penerapan model pembelajaran Two Stay Two Stray dalam pembelajaran Pendidikan Agama Kristen di kelas 5 SD Negeri Toisapu.

\section{HASIL DAN PEMBAHASAN}

Hasil Pre Tes (Tes Awal)

Tes awal dilakukan untuk mengetahui sejauh mana pemahaman atau kemampuan awal siswa. Tes awal dilakukan pada awal pertemuan di kelas dengan menggunakan model ceramah dan model Two Stay Two Stray (TSTS).

Tabel 1.Presentase Hasil Pre Tes

\begin{tabular}{|c|c|c|c|c|c|}
\hline \multirow{2}{*}{ Interval } & \multicolumn{2}{|c|}{$\begin{array}{c}\text { Model Two Stay Two } \\
\text { Stray }\end{array}$} & \multicolumn{2}{c|}{ Metode Ceramah } & \multirow{2}{*}{ Kualifikasi } \\
\cline { 2 - 5 } & Frekuensi & $\begin{array}{c}\text { Presentase } \\
(\%)\end{array}$ & Frekuensi & Presentase & \\
\hline $90-100$ & 1 & $5 \%$ & - & - & Sangat baik \\
\hline $76-89$ & 4 & $20 \%$ & 2 & $10 \%$ & Baik \\
\hline $60-75$ & 12 & $60 \%$ & 12 & $60 \%$ & Cukup \\
\hline $46-59$ & 2 & $10 \%$ & 1 & $5 \%$ & Kurang \\
\hline$<45$ & 1 & $5 \%$ & 5 & $25 \%$ & $\begin{array}{c}\text { Sangat } \\
\text { kurang }\end{array}$ \\
\hline Jumlah & 20 & $100 \%$ & 20 & $100 \%$ & \\
\hline
\end{tabular}

Tabel.1 menunjukkan kemampuan pada penggunaan model Two Stay Two Stray (TSTS) terlihat bahwa 1 orang siswa memiliki interval (90-100) dengan presentase $(5 \%)$ mendapat kualifikasi sangat baik. 4 orang siswa yang memiliki interval (76-89) dengan presentase (20\%) mendapat kualifikasi baik. 12 orang siswa yang memiliki interval (60-75) dengan presentase (60\%) mendapat kualifikasi cukup. 2 orang siswa yang memiliki interval (46-59) dengan presentase (10\%) mendapat kualifikasi sangat kurang.

Kemampuan awal siswa dengan menggunakan metode ceramah terdapat 2 orang siswa yang memiliki interval (76-89) dengan presentase (10\%) mendapat kualifikasi baik. 12 orang siswa yang memiliki interval (60-75) dengan presentase $(60 \%)$ mendapat kualifikasi cukup. 1 orang siswa yang memiliki interval (46-59) dengan presentase $(5 \%)$ mendapat kualifikasi kurang. 5 orang siswa yang memiliki interval $(<45)$ mendapat kualifikasi $(25 \%)$ sangat kurang.

\section{Hasil Post tes (Tes Akhir)}

Tes akhir dilakukan untuk mengetahui apakah siswa telah mampu menguasai indikator pada pembelajaran Pendidikan Agama Kristen. Hasil tes akhir dapat dilihat pada tabel 2 di bawah ini. 
Tabel 2.Presentase Hasil Pos Tes

\begin{tabular}{|c|c|c|c|c|c|}
\hline \multirow{2}{*}{ Interval } & \multicolumn{2}{|c|}{$\begin{array}{c}\text { Model Two Stay Two } \\
\text { Stray }\end{array}$} & \multicolumn{2}{c|}{ Metode Ceramah } & \multirow{2}{*}{ Kualifikasi } \\
\cline { 2 - 5 } & Frekuensi & $\begin{array}{c}\text { Presentase } \\
(\%)\end{array}$ & Frekuensi & Presentase & \\
\hline $90-100$ & 8 & $40 \%$ & - & - & Sangat baik \\
\hline $76-89$ & 5 & $25 \%$ & 4 & $20 \%$ & Baik \\
\hline $60-75$ & 7 & $35 \%$ & 11 & $55 \%$ & Cukup \\
\hline $46-59$ & - & - & 3 & $15 \%$ & Kurang \\
\hline$<45$ & - & - & 2 & $10 \%$ & $\begin{array}{c}\text { Sangat } \\
\text { kurang }\end{array}$ \\
\hline Jumlah & 20 & $100 \%$ & 20 & $100 \%$ & \\
\hline
\end{tabular}

Tabel 2 menunjukkan kemampuan pada penggunaan model pembelajaranTwo Stay Two Stray (TSTS) terlihat bahwa 8 orang siswa memiliki interval (90-100) dengan presentase $(40 \%)$ mendapat kualifikasi sangat baik. 5 orang siswa yang memiliki interval (76-89) dengan presentase (25\%) mendapat kualifikasi baik. 7 orang siswa yang memiliki interval (60-75) dengan presentase (35\%) mendapat kualifikasi cukup. Sedangkan kemampuan akhir siswa dengan menggunakan metode ceramah terdapat 4 orang siswa yang memiliki interval (76-89) dengan presentase (20 \%) mendapat kualifikasi baik. 11 orang siswa yang memiliki interval (60-75) dengan presentase $(55 \%)$ mendapat kualifikasi cukup. 3 orang siswa yang memiliki interval (46-59) dengan presentase (15\%) mendapat kualifikasi kurang. 2 orang siswa yang memiliki interval $(<45)$ mendapat kualifikasi $(10 \%)$ sangat kurang.

\section{Hasil Penilaian Aspek Afektif}

Penilaian terhadap sikap siswa dengan penggunaan model Two Stay Two Stray (TSTS) dan metode ceramah dapat dilihat pada tabel berikut ini :

Tabel 3.Presentase Penilaian Hasil Afektif

\begin{tabular}{|c|c|c|c|c|c|}
\hline \multirow{2}{*}{ Interval } & \multicolumn{2}{|c|}{$\begin{array}{c}\text { Model Two Stay Two } \\
\text { Stray }\end{array}$} & \multicolumn{2}{c|}{ Metode Ceramah } & \multirow{2}{*}{ Kualifikasi } \\
\cline { 2 - 5 } & Frekuensi & $\begin{array}{c}\text { Presentase } \\
(\%)\end{array}$ & Frekuensi & Presentase & \\
\hline $90-100$ & - & - & - & - & Sangat baik \\
\hline $76-89$ & 2 & $10 \%$ & 7 & $35 \%$ & Baik \\
\hline $60-75$ & 10 & $50 \%$ & 7 & $35 \%$ & Cukup \\
\hline $46-59$ & 8 & $40 \%$ & 6 & $30 \%$ & Kurang \\
\hline$<45$ & - & - & - & - & $\begin{array}{c}\text { Sangat } \\
\text { kurang }\end{array}$ \\
\hline Jumlah & 20 & $100 \%$ & 20 & $100 \%$ & \\
\hline
\end{tabular}


Tabel. 3 menunjukkan pada penggunaan model pembelajaranTwo Stay Two Stray (TSTS) terdapat 2 orang siswa yang memiliki interval (76-89) dengan presentase $(10 \%)$ mendapat kualifikasi baik. 10 orang siswa yang memiliki interval (60-75) dengan presentase $(50 \%)$ mendapat kualifikasi cukup dan 8orang siswa yang memiliki interval (46-59) dengan presentase (40\%). Sedangkan dengan menggunakan metode ceramah terdapat 4 orang siswa yang memiliki interval (76-89) dengan presentase $(20 \%)$ mendapat kualifikasi baik. 11 orang siswa yang memiliki interval (60-75) dengan presentase (55\%) mendapat kualifikasi cukup. 3 orang siswa yang memiliki interval (46-59) dengan presentase (15\%) mendapat kualifikasi kurang. 2 orang siswa yang memiliki interval $(<45)$ mendapat kualifikasi $(10 \%)$ sangat kurang.

\section{Hasil Penilaian Aspek Psikomotor}

Tabel 4. Presentase Penilaian Hasil Psikomotor

\begin{tabular}{|c|c|c|c|c|c|}
\hline \multirow{2}{*}{ Interval } & \multicolumn{2}{|c|}{$\begin{array}{c}\text { Model Two Stay Two } \\
\text { Stray }\end{array}$} & \multicolumn{2}{c|}{ Metode Ceramah } & \multirow{2}{*}{ Kualifikasi } \\
\cline { 2 - 5 } & Frekuensi & $\begin{array}{c}\text { Presentase } \\
(\%)\end{array}$ & Frekuensi & Presentase & \\
\hline $90-100$ & - & - & - & - & Sangat baik \\
\hline $76-89$ & 20 & $100 \%$ & - & - & Baik \\
\hline $60-75$ & - & - & 20 & $100 \%$ & Cukup \\
\hline $46-59$ & - & - & - & - & Kurang \\
\hline$<45$ & - & - & - & - & $\begin{array}{c}\text { Sangat } \\
\text { kurang }\end{array}$ \\
\hline Jumlah & 20 & $100 \%$ & 20 & $100 \%$ & \\
\hline
\end{tabular}

Tabel. 4 pada penggunaan model pembelajaranTwo Stay Two Stray (TSTS) terdapat 20 orang siswa yang memiliki interval (76-89) dengan presentase $(100 \%)$ mendapat kualifikasi baik. Sedangkan dengan menggunakan metode ceramah terdapat 20 orang siswa yang memiliki interval (60-75) dengan presentase (100\%) mendapat kualifikasi cukup.

\section{KESIMPULAN DAN SARAN}

\section{Kesimpulan}

Dari hasil penelitian yang telah dilakukan dapat disimpulkan beberapa hal sebagai berikut:

1. Siswa merespon dengan baik terhadap diterapkannya model pembelajaran kooperatif tipe Two Stay Two Stray (TSTS) dalam proses pembelajaran.

2. Model pembelajaran kooperatif tipe Two Stay Two Stray (TSTS) mempengaruhi hasil belajar siswa dibandingkan dengan penggunaan metode ceramah.

3. Model pembelajaran kooperatif tipe Two Stay Two Stray (TSTS) meningkatkan keaktifan siswa dalam proses pembelajaran Pendidikan Agama Kristen di SD Negeri Toisapu. 


\section{Saran}

Hasil penelitian ini merekomendasikan beberapa saran yang penting untuk diperhatikan:

1. Guru dapat memilih model pembelajaran kooperatif tipe Two Stay Two Stray (TSTS) sebab dapat meningkatkan keaktifan dan hasil belajar Pendidikan Agama Kristen.

2. Guru perlu mengupayakan teknik, strategi, serta model pembelajaran yang dapat mengakomodir berbagai gaya belajar yang dimiliki siswa. Kecenderungan guru untuk mengajar seadanya saja (seperti hanya ceramah) akan berdampak negative pada hasil belajar siswa pada mata pelajaran Pendidikan Agama Kristen.

\section{DAFTAR PUSTAKA}

Alkitab, 2012.Lembaga Alkitab Indonesia

Arikunto, S., 2006.Prosedur penelitian suatu pendekatan praktek. Jakarta: Rineka Cipta.

Cully, I. V. 2001. Dinamika Pendidikan Kristen. Jakarta: BadanPenerbit Kristen Gunung Mulia

Dimyanti dan Mudjiono, 2009.Belajar dan Pembelajaran.Jakarta : Rineke Cipta

Enklaar, H.I,2001. PendidikanAgama Kristen. Jakarta: Badan Penerbit Kristen Gunung Mulia

Fitria, S.A, dkk. 2010. PAKEM. Surakarta : CV Teguh Karya

Hakim, T., 2005.,Belajar Secara Efektif. Jakarta : Puspaswara

Jihad, A. 2008.Evalusi Pembelajaran. Yogyakarta: Multi Pressindo.

Lie, A. 2008. Cooperative Learning.Jakarta : Erlangga

Mulyasa, 2006. Kurikulum Tingkat Satuan Pendidikan. Bandung: PT Remaja Rosda Karya

Nur, M., Ibrahim, M., Racmadiarti, F. (2000).Pembelajaran Kooperatif. Surabaya : University Press-UNESA

Nuhamara, D. 1992. Pembimbing Pendidikan Agama Kristen.Jakarta : Ditjen BImas Kristen Protestan dan UT.

Sagala, S. H. 2003. Konsep dan Maknsa Pembelajaran.Bandung : Alfa Beta

Sanjaya, H. W. 2012. Penelitian Tindakan Kelas. Jakarta : Kencana Prenada Media Group.

Slameto, 2010.Belajar dan Faktor-faktor Yang Mempengaruhi.Jakata : Rineke Cipta.

Sudjana, N. 2004.Dasar-Dasar Proses Belajar Mengajar.Bandung : Sinar Baru Algensindo

Sungkono, dkk. 2009. Pengembangan Bahan Pembelajaran SD. Jakarta : Direktorat Jenderal Pendidikan Tinggi.

Ratumanan, T. G., 2004. Belajar dan Pembelajaran, Edisi ke-2.Surabaya : Unesa University Press.

Rusman, 2010.Model-model Pembelajaran.Jakarta : Rajawali Pers

Uzer, 2008.Menjadi Guru Profesional. Bandung: Remaja Rosdakarya. 